

This is the post-print of Luckett, K. 2012. Disciplinarity in question: comparing knowledge and knower codes in sociology. Research Papers in Education. 27(1): 19-40. DOI: $10.1080 / 02671521003592655$.

It is made available according to the terms of agreement between the author and the journal, and in accordance with UCT's open access policy available:

http://www.openuct.uct.ac.za/sites/default/files/UCTOpenAccessPolicy.pdf, for the purposes of research, teaching and private study. 


\title{
Disciplinarity in question: comparing knowledge and knower codes in sociology
}

\author{
Kathy Luckett ${ }^{1}$ \\ Centre for Higher Education Development, University of Cape Town, Cape Town, \\ South Africa
}

\begin{abstract}
This paper is intended to contribute to understanding why curriculum design in a discipline with a horizontal knowledge structure (Sociology) is difficult, timeconsuming and contested. A previous paper on the same case study in one Sociology department reported that students who had completed the general Sociology major found it lacking in cohesion and coherence (Luckett 2009). In order to illustrate the problem, I selected two third year Sociology courses, Urban Studies and Diversity Studies, and set out to compare and contrast the ways in which knowledge claims are made and legitimated in these two sociological discourses. The paper also has a methodological focus, namely to demonstrate the potential of systemic functional linguistics (SFL) as a method of discourse analysis that can complement and deepen a sociological analysis - in this case, Bernstein's sociology of education and in particular his concept of 'grammaticality'. The analysis seeks to make explicit the basis for knowledge claims in these two sub-disciplines (both located in the 'discipline' of Sociology), and then to investigate how this 'grammar' is built into the criteria for assessing students. The long-term goal of this research project is pedagogical - namely, to arrive at a deeper understanding of how academic discourses work, in order to contribute to the development of more coherent curricula and more visible pedagogies with more explicit assessment criteria, for the enhancement of teaching and learning. The analysis shows that the 'grammars' of these two academic discourses, in the same discipline, are based on different ordering principles; they 'work' in different ways and are based on different ontological, epistemological and methodological assumptions. The analysis also shows that the respective 'grammars' do 'get into' the assessment criteria; the structuring principles of the knowledge act as possibilities and constraints on the agents of curriculum and pedagogy, although always in a contextually contingent manner. The paper concludes by suggesting that the use of SFL as a method of discourse analysis within a social realist sociology of education framework proved to be fruitful and worthy of further development, particularly for education development work where the quest to make explicit the criteria for producing a 'legitimate text' is critical.
\end{abstract}

Keywords: Higher education, curriculum studies, education development, sociology of education, sociology, systemic functional linguistics, legitimation code theory

\footnotetext{
${ }^{1}$ Corresponding author. Email: Kathy.Luckett@uct.ac.za
} 


\section{K.Luckett}

\section{Introduction}

The research project on which this paper reports arose in the wake of an academic review on a department of Sociology. One of the concerns raised in the review and confirmed by student opinion data, was the overall lack of coherence in the undergraduate general Sociology major, despite the many excellent individual courses on offer. An earlier paper that explores the relationship between knowledge structure and curriculum structure in Sociology, suggests that one of the causes for the lack of coherence in this major may lie in the nature of the knowledge field itself (Luckett, 2009). Using Bernstein (1999) and Maton's (2000) terminology, Sociology as a field was characterised as having weak external boundaries, a horizontal, segmental structure and a 'weak grammar', with knowledge claims that tend to be legitimated predominantly by social as opposed to epistemic relations. However, some sociologists interviewed in the 2009 study claimed that there is evidence of knowledge progression ('verticality') in their sub-fields. In Bernstein's terms, these sociologists appeared to be working with relatively 'strong grammars' compared to others working with relatively 'weak grammars'. This paper builds on these findings and sets out to make more explicit the nature of the different types of knowledge claims found in the Sociology major - with a view to contributing to the efforts of the academics concerned to develop a meta-epistemic framework for their curriculum that might assist students to navigate their way through it.

Apart from this immediate education development purpose, it is hoped that the paper has some theoretical significance. Methodologically it seeks to demonstrate the potential of Halliday's systemic functional linguistics (SFL) for analysing the 'grammars' of academic discourses in a manner that deepens and enriches Bernstein's sociology of education and in particular his concept of 'grammaticality'. The compatibility of Bernstein's sociology of education with Halliday's functional linguistics (SFL) has been noted by both the sociologists and the linguists in these respective schools (Christie, F. and Martin, J., 2007), but the promise of this collaboration is yet to be fully realised. In order to demonstrate one possible application of this collaboration, this paper uses SFL as a method of discourse analysis together with broader Bernsteinian concepts, in order to compare and contrast the knowledge discourses and curriculum practices of two third year Sociology courses, Urban Studies and Diversity Studies. The analysis aims to make explicit the ways in which knowledge claims are made and legitimated in these two subdisciplines and the ontological, epistemological and methodological assumptions on which these are based.

The research questions that framed the investigation reported on in this paper can be summarised as:

1. What are the features of the 'grammars' of these two sub-disciplines? (How is data construed, apprehended, analysed and how are knowledge claims made and validated?) How exactly do the knowledge claims made in these two fields differ?

2. How does the 'grammar' of the knowledge in the field of production (research) manifest itself in the 'evaluative rules' (assessment criteria) in the field of reproduction (pedagogy) in these two courses?

3. How adequate is Bernstein's concept of 'grammaticality' for analysing different forms of knowledge in the social sciences?

The paper is structured as follows: firstly a theoretical framework that draws on the social realist school of sociology of education and on systemic functional linguistics is 


\section{K.Luckett}

elaborated. Secondly the method used for operationalising Bernstein's concept of 'grammaticality' is described. Thereafter findings of the discourse analyses using SFL on a key reading for each course are presented for each course in turn. This is followed by a more superficial analysis of each course to show how the 'grammar' of the knowledge 'gets into' the recontextualising and evaluative rules for curriculum and pedagogy respectively.

\section{Theoretical Framework}

The theoretical framework developed for analysing knowledge, curriculum and pedagogy (with a view to practical application in the field of education development) employs macro-concepts from the sociology of education, in particular, Bernstein's pedagogic device and his typologies of knowledge, and complements these with discourse analysis at the micro-level using Halliday's (1994) SFL. Bernstein's concept of classification (with strong $\mathrm{C}+$ or weak $\mathrm{C}$ - values) is used to determine the strength of the boundaries between different discourses, agents and practices and thus their degree of specialisation. Bernstein's concept of framing (with strong F+ or weak F- values) is used to determine the extent of lecturer control over the curriculum and pedagogic contexts. The three fields of the pedagogic device, the field of production (research), the field of recontextualisation (curriculum development) and the field of reproduction (pedagogy) provided the structure for the research design (see Table 1).

Bernstein's (1999, 2000) 'broad brush' typologies of knowledge are used as a starting point. In his work on knowledge, Bernstein (1999) first distinguishes between vertical and horizontal discourse. The former is coherent, explicit, contextindependent and based on systems of hierarchical meanings that can be abstracted beyond their contexts of production. The latter is everyday common sense, contextdependent knowledge that is functionally meaningful only within its contexts of production (Maton and Muller, 2007). Education aims to induct learners into vertical discourse. Within vertical discourse Bernstein distinguishes between hierarchical and horizontal knowledge structures. The former comprise general propositions and theories that integrate and subsume knowledge at lower levels. Bernstein used the metaphor of a triangle to capture a hierarchical knowledge structure. Maton and Muller (2007) explain that this type of knowledge progresses by sharpening the tip and broadening the base of the triangle. In contrast, knowledge with a horizontal knowledge structure has a segmented structure comprised of a series of specialising discourses that have specialised criteria for the production and circulation of texts. According to Bernstein, these knowledge types 'progress' by accumulating new and usually incommensurable discourses.

According to Muller (2007), Bernstein introduced the concepts of 'grammaticality' and 'verticality' to distinguish between these two types of vertical discourse. 'Verticality' captures the capacity of a knowledge discourse to progress or build internally through the principles of integration and subsumption with increasing explanatory power. Hierarchical knowledge structures display this property whilst there are serious constraints on the capacity of horizontal knowledge structures to do so. 'Grammaticality', the key concept for this paper, captures a theory's method for dealing with the world; the degree to which (concepts in) a theory can stably identify referents in the empirical world, thus allowing the theory to be tested empirically and therefore be confirmed or disconfirmed (Moore and Maton, 2001, Muller 2007). Bernstein (2000) explains that hierarchical knowledge structures have strong 'grammars' that allow contestations to be settled through empirical procedures that can confirm 'what works' in the real world. This enables theoretical development 


\section{K.Luckett}

Table 1. Research design, selection of texts and focus of analysis

\begin{tabular}{|l|l|l|}
\hline \multicolumn{1}{|c|}{ Pedagogic Device } & \multicolumn{1}{|c|}{ Texts selected } & \multicolumn{1}{c|}{ Focus of analysis } \\
\hline Field of Production & key reading for essay & $\begin{array}{l}\text { ideational meanings: verbal } \\
\text { processes, participants, } \\
\text { circumstances, objects of } \\
\text { knowledge, definitions, classification } \\
\text { values } \\
\text { interpersonal meanings: mood, } \\
\text { modality }\end{array}$ \\
\hline $\begin{array}{l}\text { Field of } \\
\text { Recontextualisation }\end{array}$ & $\begin{array}{l}\text { course outline, essay task, } \\
\text { (interview with lecturer) }\end{array}$ & $\begin{array}{l}\text { interpersonal meanings, framing } \\
\text { values }\end{array}$ \\
\hline Field of Reproduction & $\begin{array}{l}\text { 3 marked student essays (top } \\
\text { mark, average mark, low mark) }\end{array}$ & $\begin{array}{l}\text { framing values, degree of } \\
\text { explicitness of the evaluative rules }\end{array}$ \\
\hline
\end{tabular}

to proceed objectively via empirical confirmation or disconfirmation. In Bernstein's terminology, a knowledge form with a 'strong grammar' would have a robust 'external language of description' that allows it to construe what is to count as empirical referents for the concepts it signifies and to translate these unambiguously back to the world of signs, the 'internal language of description'. A horizontal knowledge structure with a relatively 'strong grammar' such as Economics or Linguistics, is described by Bernstein as a language with 'an explicit conceptual syntax capable of relatively precise empirical descriptions and/or of generating formal modelling of empirical relations' (Bernstein 2000, 163). He further notes that these disciplines often 'achieve their power by rigorous restrictions on the empirical phenomena they address.' (Bernstein 2000, 163). But, according to Bernstein, a horizontal knowledge structure with a 'weak grammar' lacks this resource because it has weak powers of definition and empirical description. There is often contestation around the identification of referents for its theoretical concepts, leading to vague procedures for knowledge construction (that may remain tacit and largely dependent on the judgement or intuition of the knower). According to Bernstein (2000), in knowledge forms with a 'weak grammar', truth is a matter of acquiring a particular 'gaze' as opposed to mastering instruments of observation and procedures for investigation.

In this paper, I build on Bernstein's typologies but attempt to correct his deficit view of horizontal knowledge structures with 'weak grammars' by drawing on Maton's extension of Bernstein's work on knowledge. In terms of judging knowledge, Bernstein clearly favoured that with a hierarchical structure, 'strong grammar' and 'verticality' (based no his preference for a realist ontology and an empiricist epistemology), 'a theory is only as good as the principles of description to which it gives rise' (Bernstein, 2000:19). He expressed exasperation with his own discipline, sociology, for failing in this regard. Bernstein's (2000) typology of knowledges is based on an empiricist model of knowledge-building as the ideal; it thus favours the sciences of nature and over the sciences of culture. The analysis that follows shows that Bernstein's typology works well for knowledge claims about material and natural objects of study, but that it misrecognises knowledge claims based on a constructivist (or post-structuralist) epistemology where the object of study is usually textual or semiotic, i.e. where the object of study is already an interpretation of empirical reality. 


\section{K.Luckett}

In order to extend Bernstein's model, I turn to the recent work of Maton (2000, 2006, 2007, 2009).

Maton (2000) has introduced 'legitimation code theory' for analysing the generative principles by which knowledge claims are legitimated and authorised. Legitimation codes are generating principles that determine how knowledge claims are justified and what is valued as a legitimate text. According to Maton (2000), all knowledge claims are based on two empirically inseparable but analytically distinct relations: how a field constructs the relation between a knowledge claim and the object of study, the epistemic relation (ER) and how a field constructs the relation between a knowledge claim and the knowing subject, the social relation (SR).The relative settings of these two relations, 'measured' by the relative strengths of their classification and framing values, determines the legitimation code. The key to legitimation code theory is to identify which relation is dominant (Maton, 2007). Where the epistemic relation is dominant, the social relation is usually subordinate giving a 'knowledge code' reading ( $\mathrm{ER}+$ / SR-). Where the social relation is dominant, the epistemic relation is usually subordinate, giving a 'knower code' reading $(\mathrm{SR}+$ / ER-). Thus if claims about knowledge are justified on the basis of the possession of specialised knowledge, skills and procedures, then a 'knowledge code' is assumed. If knowledge claims are justified on the basis of the possession of specialised dispositions, attributes and social location, then a 'knower code' is assumed. For example, in the previous study (Luckett, 2009), the Urban Studies course was identified as an example of a 'knowledge code' (ER+, SR-) whilst the Diversity Studies course was identified as an example of a 'knower code' (SR+,ER-). 'Knowledge codes' tend to underpin hierarchical knowledge structures with 'strong grammars' whilst 'knower codes' tend to underpin horizontal knowledge structures with 'weak grammars'.

Building on Bernstein's typologies, Maton defines knowledge with a strong epistemic relation as having the capacity to classify and define material and social phenomena (objects of study) through the use of specialised procedures that, when correctly applied, produce specialised knowledge claims. The criterion for judging these knowledge claims is empirical confirmation or disconfirmation. On the other hand, where a knowledge form has weak powers of description, its knowledge claims tend to be legitimated by the authority of specialised knowers who have specialised voices, attributes and personal insights. As there is no empirically objective means for arbitrating between the claims of different knowers, disputes get settled through argument, persuasion or power, or they remain unsettled, leading to incommensurability and new sets of knowers (Maton and Muller, 2007).

Maton (2009) has usefully extended the analysis of 'knower codes' by proposing a cline from strong to weak 'knower grammars', based on the principle of the degree of openness of the code to potential knowers. He expands Bernstein's notion of an 'acquired gaze' to differentiate between a 'born gaze': the most exclusive, based on genetic or biological explanations; a 'social gaze': relatively exclusive, based on social categories such as race or gender; a 'cultivated gaze': a more inclusive gaze based on a socialised disposition that can be acquired through the right kind of education and enculturation; and a 'trained gaze': an inclusive gaze that is potentially open to all knowers, based on training in the methods and procedures of the knowledge. Maton makes the important point that the greater the inclusivity of the 'knower code', the greater the potential of the knowledge to progress through cumulative knowledge-building. Maton's work on 'legitimation codes' is helpful in showing that all forms of knowledge have both an epistemic and a social relation, 


\section{K.Luckett}

whilst his work on 'knower codes' helps one to move away from a deficit view of these forms of knowledge. But, while offering some explanatory power, these sociological typologies of knowledge remain too crude to be of much help to lecturers and students engaged in the detailed work of teaching and learning the 'grammar' of particular academic discourses (a key requirement for acquiring the 'recognition and realisation rules' for producing a legitimate text). In order to make more explicit these 'rules' and the 'grammar' for making knowledge claims, I turned to SFL to understand exactly how meanings are construed in the two discourses selected for analysis.

According to Halliday academic knowledge is primarily discursive; all the meaning is carried in texts, which are typically monological, expository and entirely constitutive of the activity (reading). Halliday views a text as a semantic unit, 'language that is doing some job in some context' (Halliday and Hasan 1985:5). The grammatical categories of SFL are viewed as the realisations of semantic patterns that are determined according to their function. One analyses how meaning is built up through the choice and use of wordings. All texts are understood to arise in specific social and institutional contexts that prescribe conventions for their production. The discourses of academic disciplines are understood as 'linguistic and semiotic practices which have evolved functionally to do specialised kinds of theoretical and practical work in social institutions' (Halliday and Martin 1993:x). Halliday (1994) identifies three meta-functions for all texts: the construction of ideational meanings (which includes experiential and logical meanings), interpersonal meanings and textual meanings. These meanings have their origin in the context of the text's situation and are analysed as the Field of Discourse, the Tenor of Discourse and the Mode of Discourse $^{2}$ respectively. This study draws on the first two meta-functions only and does not analyse textual meanings.

When analysing the Field of Discourse one looks for how a text represents the world and classifies reality by expressing ideational, representational and propositional meanings. These meanings arise from the purpose of the text. Given that Bernstein's 'grammaticality' is about how a theory relates to the empirical (and social) world, the Field of Discourse and particularly the construal of experiential meanings was a key area to explore in this study. I focused particularly on what types of Verbal Processes were selected and noted when and how Material Processes were used. Types of Participants and Circumstances were also noted. In addition, an analysis of logical relations is important for understanding how arguments, and in particular causal relations, are established - this was also a focus of the study. The analysis of the Field of Discourse also provides indicators for Bernstein's concept of 'classification'.

When analysing the Tenor of Discourse, one looks at how a text establishes interpersonal and social meanings and at how the writer indicates identities, social relations and attitudes - including towards self, the reader and the content. In a pedagogic text, an analysis of the Tenor of Discourse provides indicators for Bernstein's concept of 'framing'. In this study, I analysed the Tenor of the Discourses selectively - I looked at Modality to ascertain the degree of confidence with which authors of the key course readings made knowledge claims; I looked at how interpersonal meanings were construed to create subject positions for readers of the course readings and also for the students in the course outlines. The analysis of

\footnotetext{
${ }^{2}$ In keeping with the convention of SFL, all technical terms start with a capital letter. All direct quotes from texts are in italics.
} 
interpersonal meanings was further used to indicate the degree of explicitness of the 'evaluative rules' (what counts) in the assessment of students' work (one element of 'framing'). Space does not permit further elaboration of the SFL terminology.

\section{A Method for Operationalising Grammaticality}

Bernstein's three levels of the pedagogic device were used to structure the research design adopted for this study. Key texts for each of the two courses were selected for each level of the device, namely a key reading for the main essay of the course (field of production), the course outline and essay task (complemented by an interview with the lecturer concerned) (field of recontextualisation) and three marked student essays presenting a range of performance (field of reproduction). The analysis of texts in the fields of recontextualisation (course outlines etc.) and reproduction (marked student essays) was done less rigorously than for those in the field of production (key readings), with a focus only on trying to trace the 'grammar' of the knowledge into the 'evaluative rules' that were used to mark students' essays. The analysis of a key reading for each course, following the four steps below, is reported on below. Summaries of the analyses of the readings are provided in Tables 2 and 3 in the Appendix.

When analysing the nature of 'grammaticality' in the two key course readings, it was necessary to unpack the meaning of grammaticality in more detail using the following steps:

1. Introduction to the text, goal of the text, reasons for its selection (based on information given by the lecturer).

2. Definitions of key concepts: How is the material and social world represented? What are the objects of study? What is the classification value of the objects of study and definitions? With what degree of certainty are they made (Modality)?

3. Injunctions for apprehending and analysing data: How does one come to know? What referents in the real world and/or ideas, beliefs in the social world, instantiated in discourse, stand for concepts in the theory? How are these captured? How is the data experienced or apprehended, what methods are used to analyse and process/ manipulate it? What counts as evidence and how is it constructed?

4. Confirmation or refutation of knowledge claims by the community of knowers: Is the knowledge falsifiable? How is the theory proven or agreed upon? How are some knowledge claims judged better than others? What are the rules or criteria for doing this?

\section{Characterizations of Grammaticality in Urban Studies and Diversity Studies}

\section{A. Urban Studies:}

Hamnett, C. 1996. Social Polarisation, Economic Restructuring and Welfare State Regimes. Urban Studies 33, No.8: 1407-1430.

\section{Introduction to the text}

According to the course outline, this course 'examines the international debate on the causes and character of contemporary urban inequality' in order to 'begin to interpret the emerging patterns of inequality in South African cities (Course outline 2008, 1). The lecturer's reason for selecting this text is that it introduces students to the international debate around the nature and causes of social polarisation in global cities. 'Urban Studies' is a key journal in this sub-discipline and, although published 


\section{K.Luckett}

Appendix Table 2: Summary of analysis of Urban Studies text

\begin{tabular}{|c|c|c|c|c|}
\hline & Field & Examples & Tenor & Examples \\
\hline \multirow[t]{4}{*}{$\begin{array}{l}\text { Empirical } \\
\text { level (data) }\end{array}$} & $\begin{array}{l}\text { Material } \\
\text { Processes }\end{array}$ & $\begin{array}{l}\text { shows, demonstrates, rose, fell, } \\
\text { is growing, is declining, } \\
\text { influences }\end{array}$ & \multirow[t]{4}{*}{$\begin{array}{l}\text { Declarative } \\
\text { Mood } \\
\text { Active Voice }\end{array}$} & \multirow[t]{4}{*}{$\begin{array}{l}\text { they all show a } \\
\text { trend, all other } \\
\text { deciles fell }\end{array}$} \\
\hline & $\begin{array}{l}\text { Participants } \\
\text { (nominal groups: } \\
\text { numbers \& ratios) }\end{array}$ & $\begin{array}{l}\text { the shares of the top decile of } \\
\text { household incomes, the } \\
\text { proportion of professionals, the } \\
\text { proportion of managers and } \\
\text { employers }\end{array}$ & & \\
\hline & $\begin{array}{l}\text { Circumstances: } \\
\text { Location: Place/ } \\
\text { Time: definite }\end{array}$ & $\begin{array}{l}\text { in global cities, in different } \\
\text { cities, in London 1981-1991, in } \\
\text { New York and Los Angeles }\end{array}$ & & \\
\hline & $\begin{array}{l}\text { Manner: } \\
\text { comparison }\end{array}$ & $\begin{array}{l}\text { from } 24.8 \text { per cent of the total } \\
\text {... to } 28.3 \text { per cent, by } 4.7 \\
\text { percentage points }\end{array}$ & & \\
\hline $\begin{array}{l}\text { Mediated by } \\
\text { 'evidence' }\end{array}$ & $\begin{array}{l}\text { Participant: } \\
\text { Token (evidence) }\end{array}$ & $\begin{array}{l}\text { evidence from other Western } \\
\text { cities does not support this, } \\
\text { evidence from London suggests, } \\
\text { (it is ) to argue }\end{array}$ & $\begin{array}{l}\text { High } \\
\text { Modalisation } \\
\text { for evidence }\end{array}$ & $\begin{array}{l}\text { it is clear, this is } \\
\text { not simply, at all } \\
\text {, indeed }\end{array}$ \\
\hline \multirow[t]{3}{*}{$\begin{array}{l}\text { Causal level } \\
\text { (theory) }\end{array}$} & $\begin{array}{l}\text { Mental/ Verbal } \\
\text { Processes } \\
\text { Participants } \\
\text { (hidden) }\end{array}$ & $\begin{array}{l}\text { it is misconceived, it is argued, } \\
\text { to unpack, to theorise, to } \\
\text { examine }\end{array}$ & $\begin{array}{l}\text { Agentless } \\
\text { Passive Voice } \\
\text { Low } \\
\text { Modalisation }\end{array}$ & $\begin{array}{l}\text { may be, likely to } \\
\text { be }\end{array}$ \\
\hline & $\begin{array}{l}\text { Relational } \\
\text { Processes }\end{array}$ & $\begin{array}{l}\text { there is, is, reflects, is } \\
\text { accompanied by, have become }\end{array}$ & \multirow{2}{*}{$\begin{array}{l}\text { Low } \\
\text { Modalisation: } \\
\text { grammatical } \\
\text { metaphor } \\
\text { allows author } \\
\text { to hedge } \\
\text { claims about } \\
\text { causal } \\
\text { relations }\end{array}$} & \multirow{2}{*}{ 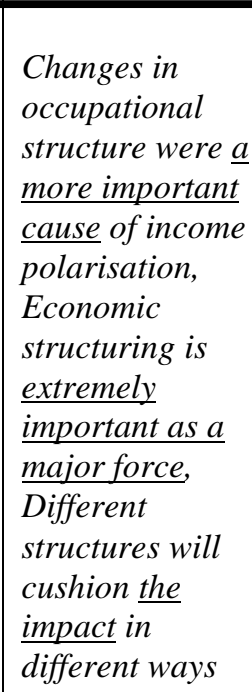 } \\
\hline & $\begin{array}{l}\text { Participants: } \\
\text { Tokens, Values } \\
\text { (abstract nominal } \\
\text { groups) }\end{array}$ & $\begin{array}{l}\text { the social polarisation of } \\
\text { occupational structures and } \\
\text { incomes, the nature and form of } \\
\text { welfare state regimes, the form } \\
\text { of economic restructuring, the } \\
\text { professionalisation of the } \\
\text { occupational structure }\end{array}$ & & \\
\hline
\end{tabular}

in 1996, this remains a central text for theorising the nature of inequality in cities. The purpose of the text is to challenge the then dominant theory on social polarization promoted by Sassen, by disproving her claim that economic restructuring (the loss of middle income manufacturing jobs to low-paid service jobs) is the main cause of both income and occupational polarisation within the paid labour force in global cities. The author achieves this by reporting on a detailed analysis of trends in census data for London (1981-1991).He is able to demonstrate that the data show that whilst there was growing income inequality in that city during this period, there was no concurrent occupational polarization - instead he argues, there was occupational professionalisation. The author then summarises a range of secondary sources on the effects of the welfare state to show that this seeming 'paradox' can be explained by 


\section{K.Luckett}

Table 3: Summary of analysis of Diversity Studies text

\begin{tabular}{|c|c|c|c|c|}
\hline & Field & Examples & Tenor & Examples \\
\hline \multirow[t]{3}{*}{$\begin{array}{l}\text { Empirical } \\
\text { level } \\
\text { (data) }\end{array}$} & $\begin{array}{l}\text { Material Processes } \\
\text { (marked) }\end{array}$ & $\begin{array}{l}\text { suffer, face, (cannot) } \\
\text { develop,(cannot) exercise }\end{array}$ & $\begin{array}{l}\text { Declarative } \\
\text { Mood } \\
\text { Active Voice }\end{array}$ & $\begin{array}{l}\text { (oppression } \\
\text { refers to the vast } \\
\text { and deep } \\
\text { injustices) some } \\
\text { groups suffer }\end{array}$ \\
\hline & $\begin{array}{l}\text { Participants } \\
\text { (oppressed groups) }\end{array}$ & $\begin{array}{l}\text { Many people, people, all } \\
\text { oppressed people, some } \\
\text { groups, the haves, the } \\
\text { have-nots, these } \\
\text { movements }\end{array}$ & $\begin{array}{l}\text { Modulation: } \\
\text { imperative: } \\
\text { obligation: high }\end{array}$ & $\begin{array}{l}\text { must be said (to } \\
\text { be oppressed), we } \\
\text { must ask, social } \\
\text { justice requires }\end{array}$ \\
\hline & $\begin{array}{l}\text { Circumstances: } \\
\text { purpose, cause, } \\
\text { matter }\end{array}$ & $\begin{array}{l}\text { for contemporary social } \\
\text { movements, for those of } \\
\text { us, for this task, among } \\
\text { others women, Blacks,... } \\
\text { Jews, Lesbians and gay } \\
\text { men, ... working-class } \\
\text { people and the physically } \\
\text { and mentally disabled. }\end{array}$ & & \\
\hline \multirow[t]{3}{*}{$\begin{array}{l}\text { Mediation } \\
\text { by Knower }\end{array}$} & $\begin{array}{l}\text { Mental: Cognitive/ } \\
\text { Verbal Processes } \\
\text { (majority) }\end{array}$ & $\begin{array}{l}\text { perceiving, unpacking, } \\
\text { interpreting, to name, } \\
\text { adopting, analysing, } \\
\text { evaluating, persuade, } \\
\text { understand, to recognise }\end{array}$ & $\begin{array}{l}\text { Definitions: } \\
\text { Modalisation: } \\
\text { low }\end{array}$ & $\begin{array}{l}\text { it is not possible } \\
\text { (to define) } \\
\text { sometimes, often, } \\
\text { partly, Nearly all, } \\
\text { if not all }\end{array}$ \\
\hline & & & $\begin{array}{l}\text { (definition of } \\
\text { social group } \\
\text { based on } \\
\text { internal } \\
\text { subjectivities) }\end{array}$ & $\begin{array}{l}\text { (a social group is } \\
\text { defined) not by a } \\
\text { set of shared } \\
\text { attributes, but by } \\
\text { a sense of } \\
\text { identity, by a } \\
\text { specific affinity }\end{array}$ \\
\hline & $\begin{array}{l}\text { Participants: author, } \\
\text { reader }\end{array}$ & I, We & $\begin{array}{l}\text { Actors, Active } \\
\text { Voice }\end{array}$ & I believe x 3 \\
\hline \multirow[t]{2}{*}{$\begin{array}{l}\text { Causal level } \\
\text { (theory) }\end{array}$} & $\begin{array}{l}\text { Relational } \\
\text { Processes: intensive/ } \\
\text { attributive }\end{array}$ & & $\begin{array}{l}\text { Declarative } \\
\text { Mood } \\
\text { (unqualified) } \\
\text { Modalisation: } \\
\text { high }\end{array}$ & $\begin{array}{l}\text { Oppression is } \\
\text { structural, These } \\
\text { kinds of } \\
\text { oppression are a } \\
\text { matter of } \\
\text { concrete power, } \\
\text { Its causes are } \\
\text { embedded in } \\
\text { unquestioned } \\
\text { norms }\end{array}$ \\
\hline & $\begin{array}{l}\text { Participants: Tokens, } \\
\text { Values (abstract } \\
\text { nominal groups) }\end{array}$ & $\begin{array}{l}\text { oppression, exploitation, } \\
\text { cultural imperialism, the } \\
\text { dominant culture, social } \\
\text { structures and practices, } \\
\text { the injustice of class } \\
\text { division, unequal } \\
\text { distributions, social } \\
\text { institutions }\end{array}$ & & \\
\hline
\end{tabular}

analyses of the effects of different welfare state regimes on the labour market, occupational structure and incomes. He succeeds in demonstrating that social polarisation takes different forms in different cities; that it is a multi-causal 
phenomenon resulting from a congruence of a range of variables that are mediated by nation states, political, economic, social and institutional contexts - including state interference in the logic of market forces. He is able to demonstrate that Sassen's theory of social polarization is not generalisable beyond the context of large US cities.

\section{Objects of study and definitions}

An analysis of the pattern of ideational meanings in the text reveals that the objects of knowledge are occupational and income structures of particular cities studied over specific periods of time. The majority of 'goings-on' (Verbal Processes) are Relational Processes between abstract nominalisations, (this is that). A minority of Mental Processes are used to express cognitive acts. These are usually used in the Agentless Passive Voice: e.g. it is misconceived, it is argued, it is viewed; or as abstract nominalisations e.g. the central argument is, it is the intention of this paper and notably the evidence suggests. The effect of this pattern is to hide the agency of the author, reader and the community of knowers. Importantly, there are a few marked Material Processes that connect the discussion to the real empirical world e.g. can and do influence, is growing, rose, fell, is declining. These claims are backed up by nine tables of data. The author's analysis of the data shows how trends in occupational and income structures are related to the key concepts, social polarisation and income polarisation. These concepts are thus shown to have an empirical grasp on the world, they are high level abstractions of 'goings-on' in the real material world.

\section{Injunctions for apprehending and analyzing data}

The lexico-grammatical patterns show that this discourse engages with the empirical world through measurement; through the capturing of precise numerical values within agreed categories that can be observed, measured and compared. In this discourse, people's experiences in the real world are located in time and space and reduced to a category of income level and occupation. The latter are sorted into agreed upon categories such as income deciles, standard socio-economic groups or categories of occupational structure. Census data can then be used to populate these categories as presences or absences (absolute numbers). In order to compare across categories the absolute numbers must be converted into ratios of the whole (percentages). When these ratios are plotted over time periods e.g. several decades, trends can be seen. Thus the method uses census data, occupational and income categories to objectify experience and convert it into numbers and then relatively simple descriptive statistics to manipulate and compare the numbers through time and across space. The analysis shows that this discourse has a means of constructing 'facts' or 'evidence' from the real world to support its knowledge claims. The 'grammar' achieves this by the use of marked Material Processes in the sections dealing with evidence and also by the precise and definite use of number and Circumstance. This relatively 'strong grammar' is based on the capacity of the discourse to capture and reduce experience to numbers that can be sorted, measured, manipulated and compared in order to identify trends and shifts in particular places for particular periods of time.

\section{Confirmation or refutation of knowledge claims}

This text operates at both the empirical and theoretical levels. When the author refers to the empirical level, he uses high Modality, i.e. he is confident about his knowledge claims. For example, in summing up his evidence for a redefinition of social polarisation, made on the basis of his analysis of the census data for London, 
the author makes strong claims using high Modality to indicate the certainty of his findings e.g. It is clear, this is not simply, at all, there is no evidence of polarization, there is no census evidence at all, they all show a trend, all the skilled groups show declines, the evidence does not support this (note evidence in Subject position). The author employs an abstract Participant evidence to mediate between the empirical and theoretical levels and makes strong claims about what the evidence can show.

However, when construing meanings at the theoretical level, particularly about cause and effect relations, the confidence with which claims are made shifts to low Modality. The author pulls back from the congruent form (x causes y) and instead causes (forces, the causes of ) and effects (impacts, outcomes) are represented as Tokens and Values in Relational Processes e.g. Changes in occupational structure were a more important cause of income polarisation, Economic structuring is extremely important as a major force. These constructions allow the author to qualify and hedge causal claims, making them harder to pin down. This position is in keeping with his argument that in open social systems, a wide range of variables operate simultaneously, with different combinations of variables coming together in different contexts. The crux of his argument against Sassen (the original theorist of social polarisation) is that contextual factors get in the way of simplistic generalisations about cause and effect and so each context (city) should be studied empirically to unearth specific explanations for social change.

Despite his caution around causal claims, the author is able to use an analysis of census data on occupational and income structures for one city to claim to have overturned the previously held definition of social polarisation. This suggests that concepts in this knowledge discourse have clear empirical referents and that the knowledge has an agreed means of progressing. This author certainly believes that the evidence supports his argument and invites the reader to support his position in the debate.

Given that sociology has been characterised as a horizontal knowledge structure with a 'weak' grammar (Bernstein, 2000), this analysis of an Urban Studies discourse suggests a relatively 'strong grammar' with relatively strongly classified concepts and procedures $(\mathrm{ER}+)$. However, the analysis also shows that its capacity to generalise and produce context-independent explanations is constrained, to some extent limiting its capacity for 'verticality'.

\section{B. Diversity Studies}

Young, I. M. 2000. Five Faces of Oppression. In Reading for Diversity and Social Justice. An anthology on racism, antisemitism, sexism, heterosexism, ableism and classism, ed. M. Adams and W.J. Blumenfeld, New York and London: Routledge.

\section{Introduction to the text}

The General Objectives in the course outline for this course in Diversity Studies states, We will draw on contemporary critical social theory to examine the way in which the construction of intersecting and often conflicting centres and margins creates differences that have a significant impact on people's life opportunities. The course also examines the construction of subject positions and identities. The course is described as consisting of a combination of examining theoretical issues and contextualising that understanding by analysing contemporary social issues such as identities, belonging, inclusion/ exclusion, centering and marginalisation, etc. (Course Outline, p.1). It is clear that this course has an emancipatory impulse; it seeks 
to change how students see the world and thereby hopes to contribute to changing society itself. It engages with students' personal and social identities as well their intellects. The object of study in this field is not empirical reality (although experiential reality sits behind the discourse), but discourse and discursive systems; it is interested in understanding how everyday ways of talking (and thinking) are used to 'construct' and reproduce social inequalities.

The text to be analysed, written by a well-known feminist, was selected by the lecturer to be read in the first week of the course because it provides students with key concepts and definitions that are used in the course and should be used in their essays. The purpose of the text is spelt out in the second paragraph: A major political project for those of us who identify with at least one of these movements must thus be to persuade people that the discourse of oppression makes sense of much of our social experience. We are ill-prepared for this task, however, because we have no clear account of the meaning of oppression. The writer then sets out to define and explain the following: oppression as a structural concept, social groups, and the five faces of oppression - exploitation, marginalization, powerlessness, cultural imperialism and violence. The chapter concludes with a section entitled Applying the Criteria. The text thus has an academic and a hortatory function: a) to do some intellectual groundwork and b) to do this as part of a political project to persuade people that a discourse of oppression is a valid description of the life experiences of a range of subordinate groups in the USA. The author identifies herself with these groups and their cause, for those of us (...) our social experience. Thus right from the start, the author makes it clear that she is not intending to provide an analysis that is value-free, but is appealing to a certain kind of knower to identify with and support her political project.

\section{Objects of study and definitions}

This text represents a world of unjust social relations that need changing. It also represents and explains theoretical concepts and their relationships. But the key object of knowledge is the discourse (of oppression) that creates social inequalities and not the material realities themselves, (see Table 3). The majority of goings-on in the text are Mental: Cognitive or Verbal Processes often used with first person Participants, $I$ and we, suggesting intellectual activity by the writer and reader (the knowers are busy (de)constructing particular discourses). The text is thus more congruent than most academic texts because the author often writes in the first person, Active Voice, foregrounding herself as a certain kind of knower. There are also many abstract Relational Processes that set out the theory and establish relationships between abstract nominalisations such as oppression and exploitation. The exception to this pattern is the use of Material Processes to describe the actual experiences of those who are oppressed e.g. suffer, and of those who are exploited e.g. are produced and reproduced, accumulate, benefit. This use of Material Processes to represent the experiential reality of people in everyday life is marked (unusual). This brief engagement with empirical reality suggests that this level of reality is not the main object of study in this knowledge discourse, empirical reality is taken as read and the intellectual work happens at a level above or behind that reality; namely on the everyday discourses used to talk about it and the power structures that permit it.

An analysis of the Tenor of this Discourse shows an interesting pattern. The writer displays high levels of certainty (high Modality) when making knowledge claims at the theoretical or causal level, e.g. These kinds of oppression are a matter of concrete power in relation to others. The other area where the discourse makes strong claims is in relation to social action, e.g. A major political project for those of us ... must thus 
be. This pattern of lexico-grammatical choices creates a subject position for the reader with a strong moral imperative to join the writer in the struggle for social justice. However, the Modality in the discourse weakens considerably when the author sets out to provide definitions, suggesting that the concepts in the discourse are neither strongly classified nor do they have empirically stable referents, e.g. it is not possible (to define) x 2, I believe x 3, sometimes, often x 2, partly x 2, Nearly all, if not all. The definition of a social group, a key unit of analysis, is based on subjectivity: a sense of identity; a specific affinity with one another suggesting that it will be difficult to operationalize empirically. This refusal to provide an objective, externalised means for categorising groups based on identifiable natural or social attributes, removes the power of researchers to define and categorise the researched.

\section{Injunctions for apprehending and analyzing data}

In this text Young claims that her Five Faces of Oppression can function as criteria for determining the existence and extent of oppression. They can be used to refute and persuade people of claims about oppression and for evaluating and adjudicating disputes. The author states, $\underline{I \text { believe that these criteria are objective. }}$ The incongruence of persuasion and belief (subjective states) juxtaposed with refutation and objectivity suggests that this is troubled terrain for the author. Exactly how knowledge claims about the existence of oppression are to be made remains vague, no specific procedures are spelt out; instead an approach (way of writing) is modelled discursively through the author's explanations of the five faces of oppression - exploitation, marginalization, powerlessness, cultural imperialism and violence.

At this point, for further clarification on the method, I probed down to curriculum level and analysed a hand-out given to students headed Diversity Literacy: A Definition. Here the lecturer makes the injunctions for constructing knowledge clearer for students. Diversity Literacy is defined as a reading practice, a way of perceiving and responding to the social climate and prevalent structures of oppression. The lecturer provides a set of criteria to be used to evaluate the presence of diversity literacy. Here again this involves mostly Mental Processes: unpacking, to translate, interpret (coded hegemonic practices); and nominalised Mental and Verbal Processes: a recognition of (the symbolic and material value of hegemonic identities , an understanding that (...), the possession of (...) a diversity grammar and vocabulary that facilitates discussion. The last of the criteria, a nominalised Material/ Behavioural Process, suggests a call to social action, an engagement with issues of transformation of these oppressive systems towards deepening democracy in all levels of social organisation. The existence of oppressive systems, hegemonic practices, etc. is taken as read.

The method for apprehending data in this knowledge discourse is to closely 'read' everyday social reality and 'deconstruct' everyday discourses and the (often implicit) common sense beliefs and ideas underpinning them that are used to justify or rationalise 'the way things are'. In this knowledge, referents in the real world do not 'stand for' concepts in the theory, the theory is designed not to answer the question 'what is the case?' but rather 'why is this the case?', with the case being already given. This not a matter of observation (sight), but a matter of 'insight' - seeing is already interpretation - it involves a particular hermeneutic, 'a way of seeing' or 'gaze'; a specialised knower must be called and cultivated to see in this way. The act of deconstruction (assessing, unpacking, interpreting, perceiving, responding) is the ability to 'see through' dominant, naturalised discourses and to 'read' these as 


\section{K.Luckett}

manifestations of hidden power structures and systems that 'constitute' and 'determine' social reality. The text suggests that the situation is complex, because a range of discourses of power operate and intersect simultaneously, constructing differences and contradictory identities and positions for subjects to take up. Symbolic (discursive) and material power are understood to work together to 'constitute' an unequal and unjust social reality. A normative subject position is created for the reader to side with the oppressed and to work for justice, democracy, etc.

\section{Confirmation or refutation of knowledge claims}

As suggested above, this knowledge discourse does not work within the rules and conventions of an empiricist epistemology where referents in the real world stand for concepts in the theory, allowing data to be gathered and analysed in a supposedly independent and objective manner. Instead an a priori normative position is taken that society is unjust (and should be changed). This normative judgment informs the sensibilities of the knower, who learns how to 'look through' (rather than at) the object of study in order to uncover the hidden structures and systems at work in society. Because this knowledge is the product of a special kind of knower, it becomes difficult to dialogue with social sciences based on different epistemic and value assumptions. The dominance of the social over the epistemic relation means that knowledge claims cannot be independently confirmed or refuted by empirical data. This leads to incommensurability of knowledges e.g. Entering the political discourse in which oppression is a central category (...) is incommensurable with the language of liberal individualism that dominates political discourse in the United States. The incommensurability of languages is one of the features Bernstein identified for horizontal knowledge structures with 'weak' (different?) 'grammars'. When comparing knowledges in this discourse, the idea that knowledge can be separated from the knower and his/her power relations and interests would be rejected. The very concept of 'objectivity' would be viewed as a mask for contingent or arbitrary power relations that construct knowledge in their own interests.

According to Bernstein, this lack of refutability removes a resource in the knowledge for achieving high levels of 'verticality'. However, according to Maton (2009), in knower codes such as this where the basis of the field is social, hierarchy exists not in the knowledge structure but in the knower structure; 'there will be a principled and hierarchical organisation of knowers based on an ideal knower and the possession of certain legitimate dispositions' (Maton, 2009: 241). In terms of Maton’s schema for a 'knower grammar', the 'grammar' of this discourse suggests the development of a 'cultivated knower' that is linked to the gaze of particular social groups. In other words, the 'gaze' entailed in deconstructing 'discourses of oppression' originates with the experiences of particular subordinated or marginal groups and the legitimation of their voice and the view that society is unjust; but it is not exclusive to people positioned in these categories. Any knower can learn to see social reality from the standpoint of the oppressed, provided they adopt a certain normative and empathetic position. But the novice knower also needs to be initiated into the specialised vocabulary and theory of diversity literacy; there are particular ways of knowing as well as particular sensibilities and dispositions. In terms of Maton's schema then, this is a relatively inclusive knower structure that is conditional upon taking up a particular political-moral position ( $\mathrm{SR}+$ ) and upon cultivating a certain theoretical facility $(\mathrm{ER}+)$. This analysis is confirmed and extended by the analysis of the Diversity Studies curriculum below. 


\section{Traces of the 'Grammar' in the Curriculum and Student Assessment}

\section{A. Urban Studies}

At the level of curriculum, (the field of recontextualisation) I analysed the course outline and essay task for traces of the 'grammar' identified in the analysis of the academic discourse (the field of production). The style of the course outline for the Urban Studies course is terse, clear and to the point. It uses high Modality of obligation, suggesting strong control by the lecturer (framing of the regulative discourse ${ }^{3}$ ), e.g. I expect, is compulsory, must be submitted. Attendance at all lectures and tutorials is compulsory, submission dates are specified by day and time, and word lengths are precise. Students are addressed as individuals, but usually in the Agentless Passive Voice. All this suggests a strongly framed regulative discourse that may be based on implicit, positional, hierarchical relations (Gamble and Hoadley, 2008).

The essay title for assessment is clear and demanding; typically it uses the Interrogative and Imperative Mood: Are global cities becoming professionalised or polarised? What do these processes mean for occupational and racial inequality? Answer this question by drawing comparisons between a number of cities, including Johannesburg and Cape Town. The essay demands that students understand the key concepts and the debates in the literature (such as the Hamnett article analysed above) and also that they are able to understand the procedures for constructing evidence in order to make comparisons across cities.

When asked in the interview what graduate attributes he aims to develop, this lecturer responded that his main aim is to teach students to think about evidence and its relation to theory. He added, it boils down to being able to conceptualise and develop ideas about how things might be and then using a range of methods to see how they actually are (...) and then testing out the theory. (...) So I focus a lot on teaching method.

With regard to pedagogy (the field of reproduction), I tried to elicit an articulation of the 'evaluative rules' by questioning the lecturer on what he looks for when marking the essays. He listed the following abilities: clear definitions (taken from the literature), logical reasoning, measuring and using ratios for comparison, the ability to understand and construct long-term trends across time and space, the need to understand the complexity of cause and effect - there are unlikely to be mono-causal explanations - we deal with multiple variables and you need to understand how context interferes with causality; I try to show students that we must work with theories and evidence, theories must be backed up by evidence and evidence must be able to disprove the theory.

The fact that this lecturer can provide a comprehensive and explicit articulation of what he looks for in student performance suggests that the classification and framing of his instructional discourse (including the 'evaluative rules') is likely to be strong, i.e. explicit.

For a closer look at playing out of the 'evaluative rules', I analysed three marked student essays. The top essay made the point that deindustrialisation (a decline in manufacturing jobs) is not the only cause of social polarisation and that the dominant social polarisation thesis incorrectly classifies the service sector by ignoring a middle income group in this sector. The student adopted a multi-causal analysis of occupational trends in global cities (the marker approvingly notes: good reasoning!).

\footnotetext{
${ }^{3}$ Within pedagogic discourse, Bernstein distinguishes between 'instructional discourse' - the overt communication of content, skills etc. and 'regulative discourse' - the more implicit forms of communication that maintain the social and moral order necessary for instruction to occur.
} 
This student was able to make sensible evidence-based comparisons across different cities and interestingly, stated in her conclusion that it is impossible to generalise across cities. This essay was awarded 85\% with the comment Excellent! - suggesting that this student had fully met the requirements of the 'evaluative rules' and produced a legitimate text.

Essays that scored low marks confused definitions, e.g. between professionalisation and polarisation, between middle-income jobs and middle-class jobs (lecturer comment) and failed to distinguish between a growing income gap (inequality) and occupational structure professionalisation (which ignores the unemployed) (lecturer comment). These essays could not sustain an evidence-based argument; the lecturer wrote: Not enough statistical evidence to draw a conclusion and Is there enough statistical evidence for your conclusion? One student listed sets of descriptive statistics without being able to articulate their significance. He also failed to articulate the conditions under which certain theories hold. These students received low marks for failing to adequately acquire the 'recognition and realisation rules', thus failing to produce legitimate texts.

The knowledge discourse's relatively 'strong grammar', based on the legitimation of knowledge claims through the use of evidence, reappears in a strong framing of the 'evaluative rules'. This was confirmed in the following statements given by the lecturer as general feedback to students on the essays: I expect students to interrogate the evidence used in the readings. (...) One way to improve your exam marks is to discuss the evidence that is advanced by authors to support their theories i) you can discuss how the evidence supports the theory, and/or ii) you can identify weaknesses in the evidence.

To sum up, the relatively 'strong grammar' of Urban Studies in the field of production is reflected in this particular course at the levels of curriculum and pedagogy as follows: A curriculum based on a knowledge form with strongly classified concepts and procedures $(\mathrm{ER}+)$ is presented to students through a strongly framed instructional discourse (high levels of teacher control). The regulative discourse is traditional, hierarchical and strongly framed, but because it is positional, remains largely implicit. The 'evaluative rules' are explicit, that is, strongly framed. These are applied strictly by the marker, leading to a demanding and discriminating assessment task.

\section{B. Diversity Studies}

At the level of curriculum (the field of recontextualisation) I analysed the course outline, a written version of the lecturer's introduction to the Diversity Studies programme and drew on an earlier interview with the lecturer. At the level of pedagogy, (the field of reproduction), I looked at an essay task and how it was marked for traces of the 'grammar' and the 'gaze' identified in the analysis of the key reading.

The course-outline is detailed and warmly invites students not only to learn from the course but also to engage with the issues presented. It soon becomes apparent that this is not a traditional, strongly framed university course. First and second person pronouns, we and you are used frequently as Actors/ Subjects in the text. This acknowledgement of the students' agency and value as persons is sustained in the marking of essays where they are addressed by their first names. The course outline states that the course looks closely at the deeply personal issues of gender and sexuality and examines the construction of subject positions and identities. Two further noteworthy features in the course-outline are firstly, the extent to which the real world is invited into the classroom. Two days per week are dedicated to 
experiential activities and for discussing hot topics. This suggests that the content of the course is relatively weakly classified - selected everyday experience and cultural artefacts are brought in for analysis. This lecturer describes her teaching as both socially responsive and socially engaged. In addition, there is a strong emphasis on group/ team work. Students are informed that the course is designed according to principles of co-operative learning. A choice of high Modality: obligation indicates the importance placed on this aspect of the course by the lecturer: you will be expected to approach the course as a team, all classes will be participatory, you will be assigned to base groups. $25 \%$ of the final mark is based on group work - a high proportion in this research-intensive institution. This indicates a belief that students can learn from each other and should be encouraged to share their experiences with each other. In a recently de-segregated society, working closely on sensitive issues in diverse groups may well be a new experience for some students.

When asked what graduate attributes she aims to develop, this lecturer stated that she hopes to give students strategies to deconstruct the discursive constructions that fix certain groups of marginalised peoples in disadvantaged positions. She hopes that students will learn to interpret and decode normal society (...) we need people who do self-reflexive work in society. She mentioned the importance of helping students to find their own voice and learning to position themselves in society. She hoped that students would develop the following dispositions: sensitivity, critical thinking, a respectful attitude, justice, fairness and a bit of outrage! She emphasised the importance of coming to know from an empathetic position, from an imaginative capacity to understand the people you are studying. Note the emphasis on developing the strategies and capacities of a certain kind of knower (SR+). Many of these attributes are inner qualities that are very difficult to objectify and measure in an assessment performance. This may perhaps explain the importance placed on group work in this course.

At the level of pedagogy, I tried to elicit an articulation of the 'evaluative rules' and to see how these were sustained in the marking of essays. The essay task involved an analysis of a newspaper article titled Blonde discrimination no joke. The article reports on a protest in Budapest by blonde women to petition the Hungarian government to ban blonde jokes. Students are asked to discuss Should this be taken seriously as a diversity issue? Do these jokes have a real social function? Why would one want to raise this issue? Why would one want to close down this issue?

In her introductory text, the lecturer had set out key ideas for this course: the social is constructed and contested by different interests; power circulates through the construction of discourses; processes of hegemony make certain discourses appear 'neutral' and 'objective'. A closer questioning about what she was looking for in this particular essay revealed the importance of students recognising that oppression operates through different discourses that function at different levels, e.g. blondes may suffer gender stereotyping but not exploitation, (although in certain circumstances an argument for a particular type of exploitation could be made - they can cooperate with patriarchy to get privileges); oppressive discourses such as white male patriarchal discourse do have material as well as symbolic effects. The lecturer also mentioned the importance of students demonstrating that they are developing a diversity literacy vocabulary by correct usage of concepts used in the assigned readings. This was specifically emphasised for students in the rubric on how to write the essay.

The essay with top marks pointed out that the blonde stereotype is a construction of white patriarchy, a racialised beauty where race and gender intersect, Blonde jokes 


\section{K.Luckett}

allow heterosexual white males to keep the upper hand. The student also pointed out that these women are still part of the dominant privileged group, in contrast to black women who are disadvantaged across race, class and gender lines. In contrast, weak essays were not able to distinguish between the oppression of blondes and that of Jews and blacks (also mentioned in the article). Furthermore, they were unable to articulate the complexity of the 'dumb blonde' stereotype as a construction of white patriarchy, an idealised, racialised, sex object who can also use her beauty to attain material privileges.

Despite the apparent 'weakness' of the 'grammar' of this discourse, as defined by Bernstein, this brief investigation into the marking of essays suggests that the lecturer has a very clear idea of what she is looking for in terms of the theory and concepts to be used by students for deconstructive analysis. Students are required to deal with complex social issues in a particular and nuanced way. Whilst it may not be as easy in this discourse, as it is in a discourse with a 'strong grammar', to make the 'evaluative rules' explicit, this brief probe into the assessment of students indicates that there certainly are strongly framed requirements for producing the correct kind of analysis. In addition, there are requirements for becoming a 'certain kind of knower' e.g. the high Modulation used around participation and group work. This may well be linked to the explicit position-taking required of writers (and readers) of this discourse. However, this strong framing of the regulative discourse is to some extent masked by the lecturer's deliberate attempt to reduce the power she exercises over students in order to develop an ethos of democracy and social justice on the course. She does this through using a personal means of control, i.e. by weakening the framing of the hierarchical relations (Gamble and Hoadley, 2008). This tentative analysis of the pedagogic discourse of the Diversity Studies course shows strong framing for the development of the theoretical concepts that inform the lens or the 'gaze' (e.g. the marker's insistence on correct usage of the diversity literacy vocabulary). This is sustained in the instructional discourse, particularly through the strong framing of the 'evaluative rules'. Despite the weak framing of the hierarchical rules (through using a personal form of control), there is evidence of a strong framing of the regulative discourse, linked to the importance of cultivating a particular kind of knower.

\section{Discussion}

The analysis has shown that the academic discourses, on which these two courses are based, are housed in the same discipline, but based on very different 'grammars'. The 'grammar' of the Urban Studies discourse can be summarised as follows: One does research at the empirical level using predefined and widely accepted categories for capturing the data. Findings are experienced as observation of numerical trends that are viewed as evidence for claims made at the theoretical level. There is agreement that knowledge claims must be backed up by evidence and this enables the achievement of some degree of 'verticality'. The price that this discourse pays for being able to substantiate its knowledge claims with empirical evidence is the reduction and objectification of human experience (e.g. of job loss and inequality) to quantities (presences or absences in cells in a table). This discourse deals cautiously with causality at the structural level. Causality at this deeper level is partly inferred inductively from constant conjunctions (patterns of regularities of specified variables) at the empirical level and partly achieved retroductively through argumentation. The discourse makes modest claims about cause and effect relations because these social scientists recognise that they are dealing with complex, open systems in which numerous variables are at work at different levels. Generalisations across time and 


\section{K.Luckett}

space are likely to be questioned; explanations are likely to hold only for specific cities or national contexts.

In contrast, the 'grammar' for the Diversity Studies discourse works as follows: Knowledge claims are based on the a priori adoption of a particular standpoint or value commitment based on a particular reading of the everyday experience of subordinate groups. The knower needs to develop a certain lens, literacy, vocabulary and disposition (i.e. become a specialised knower) in order to undertake cognitive acts that enable her to penetrate everyday social reality and go directly to deep structure where strong claims about causality are made (see the high Modalisation in the lexico-grammar around causal claims). Such a knower learns how to 'read' everyday social and cultural realities by deconstructing the discourses employed to 'construct' or maintain them. Tools and procedures for working at the empirical level are weakly classified and defined because this is not the focus or purpose of the knowledge form. Objectified instruments and procedures are not necessary because the specialised knower herself is the research instrument. Other knowledge discourses may be incommensurate with this one because they are based on different and opposing $a$ priori positions or value commitments -these standpoints are normative and therefore not empirically falsifiable; thus there is no empirical means of settling disputes between different knowledge claims.

Although both course convenors claim to be committed to working for social equality (i.e. motivated by the 'emancipatory interest' (Habermas 1971)), the discourses that they work with go about this in very different ways. The one is based on an empiricist epistemology and works inductively (without achieving generalisation) from the empirical to the causal, using quantitative instruments and procedures typical of the 'technical interest'. The other is based on a constructivist epistemology and works retroductively from normative judgements and insights into the causal to the experiential, using approaches typical of the 'hermeneutic interest' (Habermas 1971). The one asks immanent questions and legitimates its knowledge claims on the basis of empirical evidence whilst the other asks transcendental questions and wins legitimacy through elegant theorising and the moral rectitude of its position. The fundamentally different approaches found in these two fields, suggests that they will not be able to 'speak to each other' let alone build on each other in the Sociology major. Bernstein was correct to typify Sociology as a horizontal knowledge structure where incommensurable knowledge discourses accumulate alongside each other, without subsumption. One wonders whether it should be classified as a discipline at all?

The contrasts between the two discourses were borne out in the different curricula and pedagogic styles of the two lecturers concerned. The first lecturer, teaching a 'knowledge code', focused on ensuring that students followed the correct procedures and methods for making knowledge claims, without paying much explicit attention to social relations which remained conventionally hierarchical (a 'trained gaze'). In contrast, the second lecturer, teaching a 'knower code' exerted less control over procedures and content, encouraging students to bring their everyday social realities into the classroom. However, she exerted far more explicit control over what sort of knower was legitimate in her classroom (a 'cultivated gaze').

Questions around the 'grammaticality' of knowledge are embedded in larger epistemological, ontological and methodological debates. The first discourse would be characterised by Bernstein (2000) as having a relatively 'strong grammar', the second as a having a relatively 'weak grammar'. However, by using SFL to show exactly how meanings for making knowledge claims are construed, a richer 
description of the 'grammars' was provided than that conveyed by Bernstein's partisan adjectives 'strong' and 'weak', (based on his preference for a realist ontology, an empiricist epistemology and a naturalistic model of social science). The analysis showed that the Diversity Studies discourse does have an articulated epistemic relation, but not one that Bernstein's concept of 'grammatically' can recognise. I suggest that SFL provides an 'objectifying technique' for uncovering the properties of the 'grammar' of a discourse; making it possible to take the debate beyond Bernstein's rather crude binaries. Whilst 'grammaticality' is a fertile and important concept, the way in which Bernstein has conceptualised it leads inevitably to a deficit view of social science based on a constructivist epistemology. SFL has the potential to correct this because it understands discourse to both represent the world and to signify it. This position views knowledge as a product of both inter-discursive (social) and referential (epistemic) relations (Maton, 2000) thus opening up the possibility of a way through the hitherto unproductive 'paradigm wars'.

\section{Conclusion}

The analysis has shown that the 'grammars' of two selected sub-disciplines in Sociology work in very different ways. The analysis has also pointed up some of the limitations of Bernstein's concept of 'grammaticality', particularly with regard to understanding academic discourses based on constructivist epistemologies. It is suggested that the question of the relationship between the 'grammar' of an academic discourse and the curriculum and pedagogy designed to teach is a matter of case by case empirical and textual work. It is hoped that this paper has contributed to this question by demonstrating that a fine-grained account of the 'grammar' of a discourse (such as that provided by SFL) is necessary before one can understand how its 'rules' get 'recontextualised' into a curriculum and into the evaluation of students' work. As a tentative generalisation, it is suggested that the 'grammar' of a discourse in the field of production has generative powers in relation to the curriculum that can be designed and taught in the fields of recontextualisation and reproduction. In other words, the 'grammar' provides structural possibilities for and constraints on the development of a pedagogic discourse. The answer to the question of exactly how the potential of these properties and powers is realised in a specific curriculum is a matter of contingency, context and agency (in particular the agency of the lecturer and the student) - requiring empirical research in specific institutional and pedagogic contexts.

At a more practical level, an understanding of exactly how knowledge claims come to be made in particular academic discourses could be a vital resource for informing curriculum and pedagogic strategies, particularly in education development work where 'rules' and criteria need to be made as explicit as possible. However, the development of a meta-language that is both methodologically robust and accessible to those who teach and learn, remains a challenge.

\section{References}

Bernstein, B. 2000. Pedagogy, Symbolic Control and Identity: Theory, Research, Critique. Lanham: Rowman \& Littlefield Publishers, Inc.

Bernstein, B. B. 1999. Vertical and Horizontal Discourse: An Essay. British Journal of Sociology of Education 20, no.2: 157-173.

Christie, F. and Martin, J. R. (Eds) 2007. Language, Knowledge \& Pedagogy: Functional Linguistic and Sociological Perspectives. London: Continuum, 
Gamble, J. and Hoadley, U. 2008. Positioning the Regulative. Paper presented at the $5^{\text {th }}$ Basil Bernstein Symposium, July 9-12, at University of Cardiff.

Habermas, J. 1971. Knowledge and Human Interests. Boston: Beacon Press.

Halliday, M. A. K. 1994. An Introduction to Functional Grammar. London: Arnold.

Halliday, M. A. K. and Hasan, R. 1985. Language, Context and Text: Aspects of language in a social-semiotic perspective. Victoria: Deakin University.

Halliday, M. A. K. and Martin, J. R. 1993. Writing Science: Literacy and discursive power. Basingstoke: Burgess Science Press.

Luckett, K. 2009. The relationship between knowledge structure and curriculum: a case study in sociology Studies in Higher Education 34, no.4: 441-454.

Maton, K. 2000. Languages of Legitimation: the structuring significance for intellectual fields of strategic knowledge claims. British Journal of Sociology of Education 21, no.2: 147 - 167.

Maton, K. 2006. On Knowledge Structures and Knower Structures. In Knowledge, Power and Educational Reform: Applying the sociology of Basil Bernstein, ed. R. Moore, M. Arnot, J. Beck, and H. Daniels, London: Routledge.

Maton, K. 2007. Knowledge-Knower Structures in Intellectual an Educational Fields. In Christie, F. and Martin, J. R. (Eds), Language, Knowledge and Pedagogy: Functional linguistic and sociological perspectives (pp. 87-108).London: Continuum.

Maton, K. 2009. Analysing Knowledge Claims and Practices: Languages of Legitimation. In Social Realism, Knowledge and the Sociology of Education: Coalitions of the Mind, ed. K. Maton and R. Moore, London: Continuum.

Maton, K. and Muller, J. 2007. A Sociology for the Transmission of Knowledges. In Language, Knowledge and Pedagogy. Functional Linguistic and Sociological Perspectives, ed. F. Christie and J.R. Martin, 14-33. London: Continuum.

Moore, R. and Maton, K. 2001. Founding the Sociology of Knowledge: Basil Bernstein, intellectual fields, and the epistemic device. In Towards a Sociology of Pedagogy: The contribution of Basil Bernstein to research, A. Morais, I. Neves, B. Davies, H. Daniels, 153-182.New York: Peter Lang. Muller, J. 2007. On splitting hairs: Hierarchy, knowledge and the school curriculum. In Language, Knowledge and Pedagogy: Functional Linguistics and Sociological Perspectives, ed. F. Christie and J.R. Martin,65-86. London: Continuum. 


\section{K.Luckett}

Table 1. Research design, selection of texts and focus of analysis

\begin{tabular}{|l|l|l|}
\hline \multicolumn{1}{|c|}{ Pedagogic Device } & \multicolumn{1}{|c|}{ Texts selected } & \multicolumn{1}{c|}{ Focus of analysis } \\
\hline Field of Production & key reading for essay & $\begin{array}{l}\text { ideational meanings: verbal } \\
\text { processes, participants, } \\
\text { circumstances, objects of } \\
\text { knowledge, definitions, classification } \\
\text { values } \\
\text { interpersonal meanings: mood, } \\
\text { modality }\end{array}$ \\
\hline $\begin{array}{l}\text { Field of } \\
\text { Recontextualisation }\end{array}$ & $\begin{array}{l}\text { course outline, essay task, } \\
\text { (interview with lecturer) }\end{array}$ & $\begin{array}{l}\text { interpersonal meanings, framing } \\
\text { values }\end{array}$ \\
\hline Field of Reproduction & $\begin{array}{l}\text { 3 marked student essays (top } \\
\text { mark, average mark, low mark) }\end{array}$ & $\begin{array}{l}\text { framing values, degree of } \\
\text { explicitness of the evaluative rules }\end{array}$ \\
\hline
\end{tabular}




\section{Appendix Table 2: Summary of analysis of Urban Studies text}

\begin{tabular}{|c|c|c|c|c|}
\hline & Field & Examples & Tenor & Examples \\
\hline \multirow[t]{4}{*}{$\begin{array}{l}\text { Empirical level } \\
\text { (data) }\end{array}$} & Material Processes & $\begin{array}{l}\text { shows, demonstrates, rose, fell, is growing, is } \\
\text { declining, influences }\end{array}$ & \multirow[t]{4}{*}{$\begin{array}{l}\text { Declarative Mood } \\
\text { Active Voice }\end{array}$} & \multirow[t]{4}{*}{$\begin{array}{l}\text { they all show a trend, all other } \\
\text { deciles fell }\end{array}$} \\
\hline & $\begin{array}{l}\text { Participants (nominal groups: } \\
\text { numbers \& ratios) }\end{array}$ & $\begin{array}{l}\text { the shares of the top decile of household incomes, the } \\
\text { proportion of professionals, the proportion of } \\
\text { managers and employers }\end{array}$ & & \\
\hline & $\begin{array}{l}\text { Circumstances: Location: } \\
\text { Place/ Time: definite }\end{array}$ & $\begin{array}{l}\text { in global cities, in different cities, in London 1981- } \\
\text { 1991, in New York and Los Angeles }\end{array}$ & & \\
\hline & Manner: comparison & $\begin{array}{l}\text { from } 24.8 \text { per cent of the total ... to } 28.3 \text { per cent, by } \\
4.7 \text { percentage points }\end{array}$ & & \\
\hline $\begin{array}{l}\text { Mediated by } \\
\text { 'evidence' }\end{array}$ & $\begin{array}{l}\text { Participant: } \\
\text { Token (evidence) }\end{array}$ & $\begin{array}{l}\text { evidence from other Western cities does not support } \\
\text { this, evidence from London suggests, (it is ) to argue }\end{array}$ & High Modalisation for evidence & $\begin{array}{l}\text { it is clear, this is not simply, at } \\
\text { all, indeed }\end{array}$ \\
\hline \multirow[t]{3}{*}{$\begin{array}{l}\text { Causal level } \\
\text { (theory) }\end{array}$} & $\begin{array}{l}\text { Mental/ Verbal Processes } \\
\text { Participants (hidden) }\end{array}$ & $\begin{array}{l}\text { it is misconceived, it is argued, to unpack, to theorise, } \\
\text { to examine }\end{array}$ & $\begin{array}{l}\text { Agentless Passive Voice } \\
\text { Low Modalisation }\end{array}$ & may be, likely to be \\
\hline & Relational Processes & there is, is, reflects, is accompanied by, have become & \multirow[t]{2}{*}{$\begin{array}{l}\text { Low Modalisation: grammatical } \\
\text { metaphor allows author to hedge } \\
\text { claims about causal relations }\end{array}$} & \multirow{2}{*}{$\begin{array}{l}\text { Changes in occupational } \\
\text { structure were a more important } \\
\text { cause of income polarisation, } \\
\text { Economic structuring is } \\
\text { extremely important as a major } \\
\text { force, Different structures will } \\
\text { cushion the impact in different } \\
\text { ways }\end{array}$} \\
\hline & $\begin{array}{l}\text { Participants: Tokens, Values } \\
\text { (abstract nominal groups) }\end{array}$ & $\begin{array}{l}\text { the social polarisation of occupational structures and } \\
\text { incomes, the nature and form of welfare state regimes, } \\
\text { the form of economic restructuring, the } \\
\text { professionalisation of the occupational structure }\end{array}$ & & \\
\hline
\end{tabular}


Table 3: Summary of analysis of Diversity Studies text

\begin{tabular}{|c|c|c|c|c|}
\hline & Field & Examples & Tenor & Examples \\
\hline \multirow{3}{*}{$\begin{array}{l}\text { Empirical level } \\
\text { (data) }\end{array}$} & Material Processes (marked) & suffer, face, (cannot) develop,(cannot) exercise & $\begin{array}{l}\text { Declarative Mood } \\
\text { Active Voice }\end{array}$ & $\begin{array}{l}\text { (oppression refers to the vast and } \\
\text { deep injustices) some groups suffer }\end{array}$ \\
\hline & Participants (oppressed groups) & $\begin{array}{l}\text { Many people, people, all oppressed people, some } \\
\text { groups, the haves, the have-nots, these } \\
\text { movements }\end{array}$ & $\begin{array}{l}\text { Modulation: imperative: } \\
\text { obligation: high }\end{array}$ & $\begin{array}{l}\text { must be said (to be oppressed), we } \\
\text { must ask, social justice requires }\end{array}$ \\
\hline & $\begin{array}{l}\text { Circumstances: purpose, cause, } \\
\text { matter }\end{array}$ & $\begin{array}{l}\text { for contemporary social movements, for those of } \\
\text { us, for this task, among others women, Blacks, ... } \\
\text { Jews, Lesbians and gay men, ... working-class } \\
\text { people and the physically and mentally disabled. }\end{array}$ & & \\
\hline \multirow[t]{3}{*}{$\begin{array}{l}\text { Mediation by } \\
\text { Knower }\end{array}$} & $\begin{array}{l}\text { Mental: Cognitive/ Verbal } \\
\text { Processes (majority) }\end{array}$ & $\begin{array}{l}\text { perceiving, unpacking, interpreting, to name, } \\
\text { adopting, analysing, evaluating, persuade, } \\
\text { understand, to recognise }\end{array}$ & Definitions: Modalisation: low & $\begin{array}{l}\text { it is not possible (to define) } \\
\text { sometimes, often, partly, Nearly all, if } \\
\text { not all }\end{array}$ \\
\hline & & & $\begin{array}{l}\text { (definition of social group based } \\
\text { on internal subjectivities) }\end{array}$ & $\begin{array}{l}\text { (a social group is defined) not by a } \\
\text { set of shared attributes, but by a } \\
\text { sense of identity, by a specific affinity }\end{array}$ \\
\hline & Participants: author, reader & $I, W e$ & Actors, Active Voice & I believe $\mathrm{x} 3$ \\
\hline \multirow[t]{2}{*}{$\begin{array}{l}\text { Causal level } \\
\text { (theory) }\end{array}$} & $\begin{array}{l}\text { Relational Processes: intensive/ } \\
\text { attributive }\end{array}$ & & $\begin{array}{l}\text { Declarative Mood (unqualified) } \\
\text { Modalisation: high }\end{array}$ & $\begin{array}{l}\text { Oppression is structural, These kinds } \\
\text { of oppression are a matter of } \\
\text { concrete power, Its causes are } \\
\text { embedded in unquestioned norms }\end{array}$ \\
\hline & $\begin{array}{l}\text { Participants: Tokens, Values } \\
\text { (abstract nominal groups) }\end{array}$ & $\begin{array}{l}\text { oppression, exploitation, cultural imperialism, } \\
\text { the dominant culture, social structures and } \\
\text { practices, the injustice of class division, unequal } \\
\text { distributions, social institutions }\end{array}$ & & \\
\hline
\end{tabular}

